\title{
Comparative studies of callus induction and plant regeneration from mature embryos in rice mutants
}

\author{
M. A. H. M. Kamal, M. A. Z. Al Munsur, M. S. Hossain and S. Begum \\ Department of Biotechnology, Bangladesh Agricultural University, Mymensingh-2202, Bangladesh
}

\begin{abstract}
Experiments were performed with mature embryos of four rice mutants for in vitro callus induction and plant regeneration. Different concentrations of 2,4-D and BAP combined, Kn and NAA combined and MET were used to assess their effects on induction of callus, shoot and roots. Given concentrations of 2,4-D with BAP and rice mutants in vitro cultures showed that Y-1281 and Atomita-4 had produced the highest percentages of callus at 2 $\mathrm{mgl}^{-1}$ 2,4-D with $0.5 \mathrm{mgl}^{-1}$ BAP in both light and dark conditions. Similar results were obtained in terms of concentrations and genotypes when 2,4-D and BAP were used together. Combined 2,4-D and BAP treatments showed significantly higher callusing under light conditions (90\%). For shoot and root regenerations, once again the mutant genotype Y-1281 produced the highest percentages of shoots and roots and it also showed highest root length. And $11 \mathrm{mgl}^{-1} 2,4-\mathrm{D}, 0.5 \mathrm{mgl}^{-1} \mathrm{NAA}$ combined and $2.5 \mathrm{mgl}^{-1} \mathrm{MET}$ concentration resulted significantly the highest shoot and root regeneration.
\end{abstract}

Keywords: Callus induction, Mature embryos, Plant regeneration, Root induction, Rice

\section{Introduction}

Rice (Oryza sativa L.) is the most important world wide cultivated cereal crop belongs to the family Graminae. It is the world's most important food crop and a primary food source for more than a third of world's population. It is the staple food here in Bangladesh. For its importance, much emphasis has been placed on its improvement involving biotechnology (Khush, 1984; Toenniessen, 1990). Tissue culture technology had opened new avenues of research and has become an important alternative of conventional propagation procedures for the plants. This technique is being used as an adjunct to traditional means in crop improvement (Khan, 2000). The potential for genetic improvements of monocots especially of rice through tissue culture including somatic hybridization has recently been applied (Kyozuka et al., 1987). Many workers have regenerated complete plants from calli derived from embryos, anthers, shoot and root explants (Bajaj, 1991; Elhag et al., 1992). Some of the regenerated plants showed somaclonal variability in $r 1$ generation (Lutts et al., 2001). Induction of callus from rice embryo is pre-requisite for initiation of embryogenic cell suspension as a source of protoplasts for transformation and somatic hybridization experiments as well as in vitro selection for biotic and abiotic stresses. The present study was undertaken to assess the callus induction ability and plant regeneration of the potential four rice mutants and identify root induction capacity in MET treated medium.

\section{Materials and Methods}

The experiment was performed during the period from March to November, 2006 at the Tissue Culture Laboratory of Plant Breeding Division, Bangladesh Institute of Nuclear Agriculture, Mymensingh. Mature rice embryos of the four rice mutants TNDB-100, RD-2586, Y-1281 and Atomita4 were used as explants for callus initiation and subsequent regeneration. MS (Murashige and Skoog, 1962) medium used as basal medium. Different concentrations of 2, 4-D (1.0, 2.0, 2.5 and 3.0) with $0.5 \mathrm{mgl}^{-1}$ BAP was used for callus induction in light and dark. Kinetin $(\mathrm{Kn})(0.0,2.0,4.0,6.0,8.0,10$ and $11 \mathrm{mgL}^{-1}$ ) with $0.50 \mathrm{mgl}^{-1}$ NAA was used for shoot regeneration and MET (1.0, 1.5, 2.0, 2.5 and $3.0 \mathrm{mgL}^{-1}$ ) for root induction with organogenesis Mature seeds of four rice mutants were dehusked manually and then washed thoroughly in running tap water. For the surface sterilization of these dehusked seeds were immersed with $0.1 \% \mathrm{HgCl}_{2}$ solution for $10-15$ minutes followed by $4-5$ times rinsed in distilled water to remove traces of $\mathrm{HgCl}_{2}$. Sterilized mature seeds were cultured directly in MS medium supplemented with different combinations of hormones (2,4-D and BAP) for induction of callus. The calli of convenient sizes were removed and then subcultured to a freshly prepared medium for shoot differentiation. After that $3-5 \mathrm{~cm}$ shoots were separated aseptically from each other and 
transferred to freshly prepared rooting medium. The plantlets with sufficient roots were then taken out from the culture vessels and then transplanted to small pots containing sterilized ground soil mixed with cowdung. After 10-12 days acclimatization the plantlets were transferred to the field condition where they developed into mature plants.

The culture vessels with inoculated explants were incubated both in dark and light in a temperature controlled growth room $\left(25 \pm 2^{\circ} \mathrm{C}\right)$ under 16-hour photoperiod with a light intensity of 2000-3000 lux. Al instruments and media were sterilized in an autoclave at a temperature of $121^{\circ} \mathrm{C}$ for 20 minutes under $1.16 \mathrm{Kgcm}^{-2}$ pressure. Data were collected on per cent of callus initiation, per cent of shoot differentiation, per cent of root induction, length of roots, and number of plants establishment. The experiment was conducted in Completely Randomized Design with 3 replications. Statistical package MSTAT-C software, developed by Russel (1986) was used for the analysis of variance for different characters. Mean values of characters were compared by the Duncan's Multiple Range Test.

\section{Results and Discussion}

\section{Induction of Callus}

Effect of hormone: Concentrations of $2.0 \mathrm{mgl}^{-1} 2,4-\mathrm{D}+0.5 \mathrm{mgl}^{-1}$ BAP produced the highest percentages of callus in both light and dark conditions (Table 1). In contrast, concentration of $1.0 \mathrm{mgl}^{-1}$ and $3.0 \mathrm{mgl}^{-1} 2,4-\mathrm{D}+0.5 \mathrm{mgl}^{-1}$ BAP had produced significantly the lowest and lower callus percentages under both conditions. This is in partial conformity with Deng et al. (1998), Liu et al. (2001) and Luo et al. (2004) who also observed slightly better calli that well grew in the light than in the dark condition.

Variation among the mutants: The mutants Y-1281 and Atomita-4 showed significantly the highest and the second highest order of callus percentage under both light and dark conditions, although there existed significant differences from each other (Table 1). In contrast, TNDB-100 showed the least percentages of callus induction.

Table 1. Effects of rice mutant and 2,4-D concentration with added $0.5 \mathrm{mgl}^{-1}$ BAP for callus induction under light and dark condition

\begin{tabular}{|c|c|c|}
\hline Treatment effect & Light & Dark \\
\hline $2,4-\left.\mathrm{D} \mathrm{mgl}\right|^{-1}+0.5 \mathrm{mgl}^{-1} \mathrm{BAP}$ & Callus induction (\%) & Callus induction (\%) \\
\hline 1.0 & $41.25^{\mathrm{d}}$ & $37.08^{\mathrm{d}}$ \\
\hline 2.0 & $83.75^{\mathrm{a}}$ & $74.17^{\mathrm{a}}$ \\
\hline 2.5 & $71.25^{b}$ & $64.58^{b}$ \\
\hline 3.0 & $56.67^{c}$ & $51.25^{c}$ \\
\hline $\operatorname{LSD}_{(0.05)}$ & 3.287 & 3.060 \\
\hline \multicolumn{3}{|l|}{ Mutants } \\
\hline Atomita-4 & $65.00^{\mathrm{b}}$ & $59.17^{\mathrm{a}}$ \\
\hline RD-2586 & $61.25^{\mathrm{c}}$ & $53.75^{b}$ \\
\hline TNDB-100 & $58.33^{c}$ & $52.50^{b}$ \\
\hline $\mathrm{Y}-1281$ & $68.33^{\mathrm{a}}$ & $61.67^{\mathrm{a}}$ \\
\hline $\operatorname{LSD}_{(0.05)}$ & 3.287 & 3.060 \\
\hline
\end{tabular}

In a column, figures with same letters did not differ significantly

Interactions between mutants and hormone: The mutant $\mathrm{Y}-1281$ and Atomita- 4 had produced the highest numbers and percentages of callus at $0.5 \mathrm{mgl}^{-1} 2$, 4-D plus $0.5 \mathrm{mgl}^{-1}$ BAP in both light and dark conditions. In contrast, TNDB-100 and RB-2586 produced significantly the least number and percentage under light and dark conditions (Table 2).

Variations among the mutants: Of the different mutants, Y-1281 produced the highest shoot percentages (69.50) and this was ranked equal statistically with Atomita-4 for shoot percentage (68.10) (Table 3) Contrarily, TNDB-100 produced the least shoot percentages (54.6). However, the rest of the two mutants captured intermediate positions for shoot numbers and percentages. 
Table 2. Interaction effects between mutants and hormone under light and dark condition on callus induction

\begin{tabular}{|c|c|c|c|}
\hline \multirow{2}{*}{ Mutants } & \multirow{2}{*}{$\begin{array}{l}\text { Different concentration of } 2,4 \\
\qquad D+0.5 \mathrm{mgl}^{-1} \mathrm{BAP}\end{array}$} & Light & Dark \\
\hline & & Callus induction (\%) & Callus induction (\%) \\
\hline \multirow[t]{4}{*}{ Atomita-4 } & 1.0 & $38.33^{i}$ & $33.33^{i}$ \\
\hline & 2.0 & $90.00^{\mathrm{a}}$ & $80.00^{\mathrm{a}}$ \\
\hline & 2.5 & $68.33^{\text {ef }}$ & $65.00^{\text {de }}$ \\
\hline & 3.0 & $63.33^{\mathrm{fg}}$ & $58.33^{\mathrm{fg}}$ \\
\hline \multirow[t]{4}{*}{ RD-2586 } & 1.0 & $40.00^{\prime}$ & $36.67^{1}$ \\
\hline & 2.0 & $83.33^{\mathrm{a}-\mathrm{c}}$ & $73.33^{b}$ \\
\hline & 2.5 & $71.67^{\mathrm{de}}$ & $61.67^{\mathrm{d}-\mathrm{f}}$ \\
\hline & 3.0 & $50.00^{\mathrm{h}}$ & $43.33^{\mathrm{h}}$ \\
\hline \multirow[t]{4}{*}{ TNDB-100 } & 1.0 & $38.33^{i}$ & $35.00^{i}$ \\
\hline & 2.0 & $76.67^{\text {cd }}$ & $66.67^{\mathrm{cd}}$ \\
\hline & 2.5 & $65.00^{e-g}$ & $60.00^{e-g}$ \\
\hline & 3.0 & $53.33^{\mathrm{h}}$ & $48.33^{\mathrm{h}}$ \\
\hline \multirow[t]{4}{*}{ Y-1281 } & 1.0 & $48.33^{\mathrm{h}}$ & $43.33^{h}$ \\
\hline & 2.0 & $85.00^{\mathrm{ab}}$ & $76.67^{\mathrm{ab}}$ \\
\hline & 2.5 & $80.00^{b c}$ & $71.67^{\mathrm{bC}}$ \\
\hline & 3.0 & $60.00^{9}$ & $55.00^{g}$ \\
\hline $\operatorname{LSD}_{(0.05)}$ & & 6.574 & 6.120 \\
\hline
\end{tabular}

In a column, figures with same letters did not differ significantly

\section{Shoot regeneration}

Effect of kinetin: Among the different concentrations, $11 \mathrm{mgl}^{-1} \mathrm{kn}+0.5 \mathrm{mgl}^{-1}$ NAA had produced significantly the highest shoot percentages (82.5) (Table 3). In contrast, concentration of $2 \mathrm{mgl}^{-1}{ }^{1} \mathrm{kn}+$ $0.5 \mathrm{mgl}^{-1}$ NAA produced the least percentages (63.33) of shoot. This results corroborate with the results of Zhang et al. (2002) who also observed differential number and percentages of shoot initiation in their studies with different concentrations of $\mathrm{kn}+0.5 \mathrm{mgl}^{-1} \mathrm{NAA}$.

Table 3. Effect of hormone concentrations and rice mutants on shoot regeneration

\begin{tabular}{|c|c|}
\hline Treatment effect & \multirow{2}{*}{ Shoot induction (\%) } \\
\hline $\mathrm{Kn}+0.5 \mathrm{mgl}^{-1} \mathrm{NAA}$ & \\
\hline 0.0 & $00^{\mathrm{C}}$ \\
\hline 2.0 & $63.33^{d}$ \\
\hline 4.0 & $70.83^{\mathrm{C}}$ \\
\hline 6.0 & $71.67^{\mathrm{C}}$ \\
\hline 8.0 & $75.83^{b}$ \\
\hline 10.0 & $78.33^{b}$ \\
\hline 11.0 & $82.50^{\mathrm{a}}$ \\
\hline $\operatorname{LSD}_{(0.05)}$ & 3.693 \\
\hline \multicolumn{2}{|l|}{ Mutants } \\
\hline RD-2586 & $60.48^{b}$ \\
\hline Atomita-4 & $68.10^{a}$ \\
\hline TNDB-100 & $54.76^{\mathrm{C}}$ \\
\hline $\mathrm{Y}-1281$ & $69.52^{\mathrm{a}}$ \\
\hline $\operatorname{LSD}_{(0.05)}$ & 2.791 \\
\hline
\end{tabular}

In a column, figures with same letters did not differ significantly

Interaction between kinetin concentrations and rice mutants: The interaction effects between mutants and concentrations of kn showed highly significant differences ( $p>0.01)$ for percentages of shoots. The mutant $\mathrm{Y}-1281$ and Atomita-4 had produced significantly the highest percentages of shoot at concentration of $11 \mathrm{mgl}^{-1} \mathrm{kn}$ (Table 4). In contrast, RD-2586 and TNDB-100 had produced significantly least percentages of shoot in all kn concentrations apart from concentration of $11 \mathrm{mgl}^{-1} \mathrm{kn}$ +0 $5 \mathrm{mgl}^{-1}$ NAA. The results of mutants with that of kn concentrations agrees with the results of Yoshida and Oosato (1998) who also observed varietals differences versus kn concentrations. 
Table 4. Interaction effect between mutants and hormone concentrations

\begin{tabular}{|c|c|c|}
\hline Mutants & Different concentration of $\mathrm{Kn}+0.5 \mathrm{mgl}^{-1} \mathrm{NAA}$ & Shoot induction (\%) \\
\hline \multirow[t]{7}{*}{ RD-2586 } & 00 & $0.00^{\mathrm{i}}$ \\
\hline & 2.0 & $56.66^{\text {gh }}$ \\
\hline & 4.0 & $73.33^{\mathrm{ce}}$ \\
\hline & 6.0 & $70.00^{\text {de }}$ \\
\hline & 8.0 & $73.33^{\mathrm{c-e}}$ \\
\hline & 10.0 & $73.33^{\mathrm{ce}}$ \\
\hline & 11.0 & $76.66^{\mathrm{b}-\mathrm{d}}$ \\
\hline \multirow[t]{7}{*}{ Atomita-4 } & 00 & $0.00^{i}$ \\
\hline & 2.0 & $73.33^{\mathrm{c-e}}$ \\
\hline & 4.0 & $76.66^{\mathrm{b}-\mathrm{d}}$ \\
\hline & 6.0 & $76.66^{\mathrm{b}-\mathrm{d}}$ \\
\hline & 8.0 & $80.00^{a-c}$ \\
\hline & 10.0 & $83.33^{\mathrm{ab}}$ \\
\hline & 11.0 & $86.66^{\mathrm{a}}$ \\
\hline \multirow[t]{7}{*}{ TNDB-100 } & 00 & $0.00^{i}$ \\
\hline & 2.0 & $50.00^{\mathrm{h}}$ \\
\hline & 4.0 & $56.66^{\mathrm{gh}}$ \\
\hline & 6.0 & $60.00^{\mathrm{fg}}$ \\
\hline & 8.0 & $66.66^{\mathrm{ef}}$ \\
\hline & 10.0 & $70.00^{\mathrm{de}}$ \\
\hline & 11.0 & $80.00^{a-c}$ \\
\hline \multirow[t]{7}{*}{ Y-1281 } & 00 & $0.00^{i}$ \\
\hline & 2.0 & $73.33^{c-e}$ \\
\hline & 4.0 & $76.66^{\mathrm{b}-\mathrm{d}}$ \\
\hline & 6.0 & $80.00^{a-c}$ \\
\hline & 8.0 & $83.33^{\mathrm{ab}}$ \\
\hline & 10.0 & $86.66^{\mathrm{a}}$ \\
\hline & 11.0 & $86.66^{a}$ \\
\hline LSD (0.05) & & 7.358 \\
\hline
\end{tabular}

In a column, figures with same letters did not differ significantly

Effect of MET concentrations on induction of root: Among the different concentrations, $2.5 \mathrm{mgl}^{-1}$ MET produced significantly the highest root percentages $(76.66)$ and length $(2.77 \mathrm{~cm})$ of roots (Table 5). In contrast, concentration at $1.0 \mathrm{mgl}^{-1}$ MET had produced the least percentages (48.33) and length $(2.25 \mathrm{~cm})$ of roots. Similar trend of results was reported in this same line that $2.5 \mathrm{mgl}^{-1} \mathrm{MET}$ concentration appeared well for root induction media by Ahmed (2004).

Variation among the mutant: Of the different mutants, Y-1281 produced the highest root induction percentages (67.33) and root length $(2.92 \mathrm{~cm})$ while showing indifferences with Atomita-4 and RD2586 in root percentage. Contrarily, TNDB-100 produced significant least root induction percentages (57.33) and despite TNDB-100 had similar rank with RD-2586 length $(2.25 \mathrm{~cm})$ (Table 5).

Interactions of MET and rice mutants on rooting: Interaction effects between mutants and concentrations showed significant differences in root percentages and root length. In mutants varieties Y-1281 and Atomita-4 had produced comparatively the highest percentages at $2.5 \mathrm{mgl}^{-1}$ MET concentration (Table 6). 
Table 5. Effect of MET concentrations and rice mutants on root induction and root growth

\begin{tabular}{|c|c|c|}
\hline Treatment effect & Root induction (\%) & Length of root $(\mathrm{cm})$ \\
\hline \multicolumn{3}{|l|}{ Different concentration of MET } \\
\hline 1.0 & $48.33^{d}$ & $2.25^{d}$ \\
\hline 1.5 & $55.83^{c}$ & $2.55^{\mathrm{c}}$ \\
\hline 2.0 & $64.17^{b}$ & $3.40^{\mathrm{a}}$ \\
\hline 2.5 & $76.67^{\mathrm{a}}$ & $2.77^{\mathrm{b}}$ \\
\hline 3.0 & $59.17^{b}$ & $2.44^{\mathrm{c}}$ \\
\hline $\operatorname{LSD}_{(0.05)}$ & 5.734 & 0.125 \\
\hline \multicolumn{3}{|l|}{ Mutants } \\
\hline Y-1281 & $67.33^{\mathrm{a}}$ & $2.92^{\mathrm{a}}$ \\
\hline Atomita-4 & $64.00^{\mathrm{a}}$ & $2.75^{\mathrm{b}}$ \\
\hline RD-2586 & $62.67^{\mathrm{a}}$ & $2.54^{c}$ \\
\hline TNDB-100 & $57.33^{b}$ & $2.53^{\mathrm{C}}$ \\
\hline $\operatorname{LSD}_{(0.05)}$ & 5.13 & 0.111 \\
\hline
\end{tabular}

In a column, figures with same letters did not differ significantly

Table 6. Effect of different concentrations of MET in MS medium on root induction ability of shoot from embryo derived callus

\begin{tabular}{|c|c|c|c|}
\hline Mutants & Different concentration of $\mathrm{MET} \mathrm{mgL}^{-1}$ & Root induction (\%) & Length of root $(\mathrm{cm})$ \\
\hline \multirow[t]{5}{*}{ Y-1281 } & 1.0 & $43.33^{i}$ & $2.47^{\mathrm{e}-\mathrm{h}}$ \\
\hline & 1.5 & $63.33^{\mathrm{d}-\mathrm{g}}$ & $2.88^{\mathrm{cd}}$ \\
\hline & 2.0 & $70.00^{b-e}$ & $3.66^{\mathrm{a}}$ \\
\hline & 2.5 & $83.33^{\mathrm{a}}$ & $2.93^{\mathrm{C}}$ \\
\hline & 3.0 & $76.66^{\mathrm{a}-\mathrm{c}}$ & $2.70^{\mathrm{cd}}$ \\
\hline \multirow[t]{5}{*}{ Atomita-4 } & 1.0 & $53.33^{g-1}$ & $2.26^{g-i}$ \\
\hline & 1.5 & $56.66^{\mathrm{e}-h}$ & $2.46^{\mathrm{e}-\mathrm{h}}$ \\
\hline & 2.0 & $66.66^{\mathrm{c-f}}$ & $3.36^{b}$ \\
\hline & 2.5 & $73.33^{\mathrm{a}-\mathrm{d}}$ & $3.30^{b}$ \\
\hline & 3.0 & $70.00^{b-e}$ & $2.36^{f-i}$ \\
\hline \multirow[t]{5}{*}{ RD-2586 } & 1.0 & $50.00^{g-i}$ & $2.10^{i}$ \\
\hline & 1.5 & $53.33^{f-i}$ & $2.56^{\mathrm{d}-\mathrm{f}}$ \\
\hline & 2.0 & $63.33^{\mathrm{c}-\mathrm{g}}$ & $3.40^{\mathrm{b}}$ \\
\hline & 2.5 & $80.00^{a b}$ & $2.50^{e-g}$ \\
\hline & 3.0 & $66.66^{c-f}$ & $2.10^{i}$ \\
\hline \multirow[t]{5}{*}{ TNDB-100 } & 1.0 & $46.66^{\text {hi }}$ & $2.20^{\mathrm{hi}}$ \\
\hline & 1.5 & $50.00^{\mathrm{hi}}$ & $2.33^{f-1}$ \\
\hline & 2.0 & $56.66^{\mathrm{e}-h}$ & $3.20^{b}$ \\
\hline & 2.5 & $70.00^{b-e}$ & $2.36^{f-i}$ \\
\hline & 3.0 & $63.33^{\mathrm{c}-\mathrm{g}}$ & $2.26^{\mathrm{d}-\mathrm{f}}$ \\
\hline $\operatorname{LSD}_{(0.05)}$ & & 11.47 & 0.25 \\
\hline
\end{tabular}

In a column, figures with same letters did not differ significantly

\section{Establishment of Plants}

After sufficient development of shoot and root systems, the small plantlets were taken out from the culture vessels with proper care without damaging the roots. The plantlets were then transplanted in small pots. When the plantlet grew to a height of $8-10 \mathrm{~cm}$, then were transferred to plastic pots. The growth condition and the tillering capacity of plantlets were satisfactory. The pots with the established plants were then kept in natural condition, allowed them to grow up to maturity with proper care. The survivability of the plant was $95 \%$. 


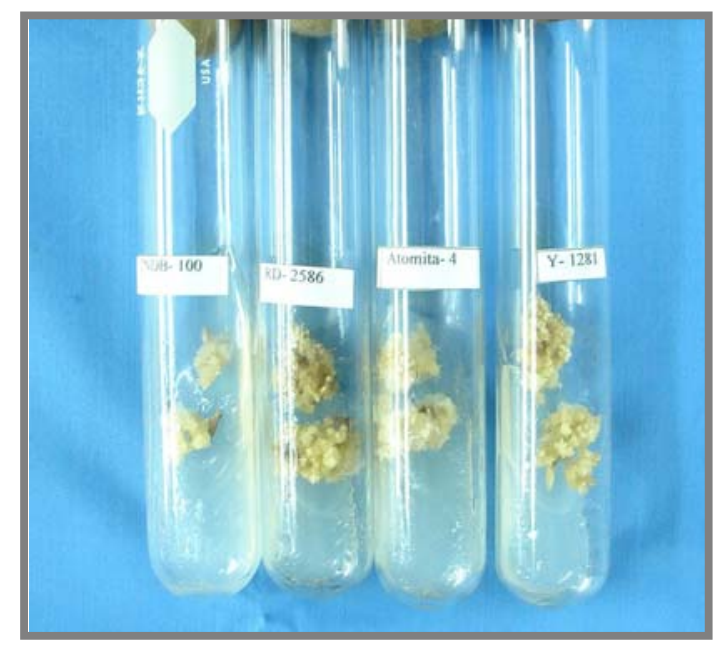

Plate 1. Callus induction from mature embryos of four rice mutants on medium containing $2.0 \mathrm{mgl}^{-1} 2$, 4-D with $0.5 \mathrm{mgl}^{-1}$ BAP under light condition (DAl: 25)

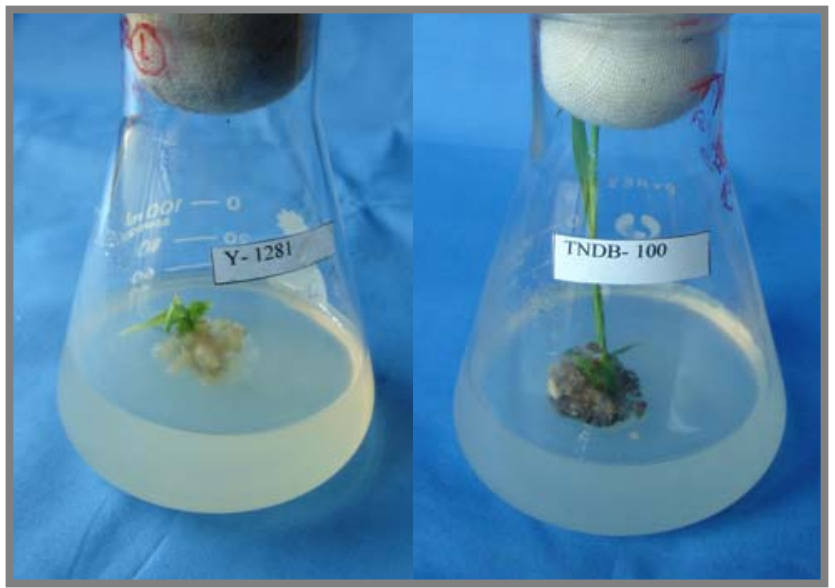

Plate 2. Shoot regeneration from callus of $Y-1281$ (highest) and TNBD-100 (lowest) on medium containing $11 \mathrm{mgl}^{-1} \mathrm{Kn}$ with $0.5 \mathrm{mgl}^{-1} \mathrm{NAA}$ (DAl:35)

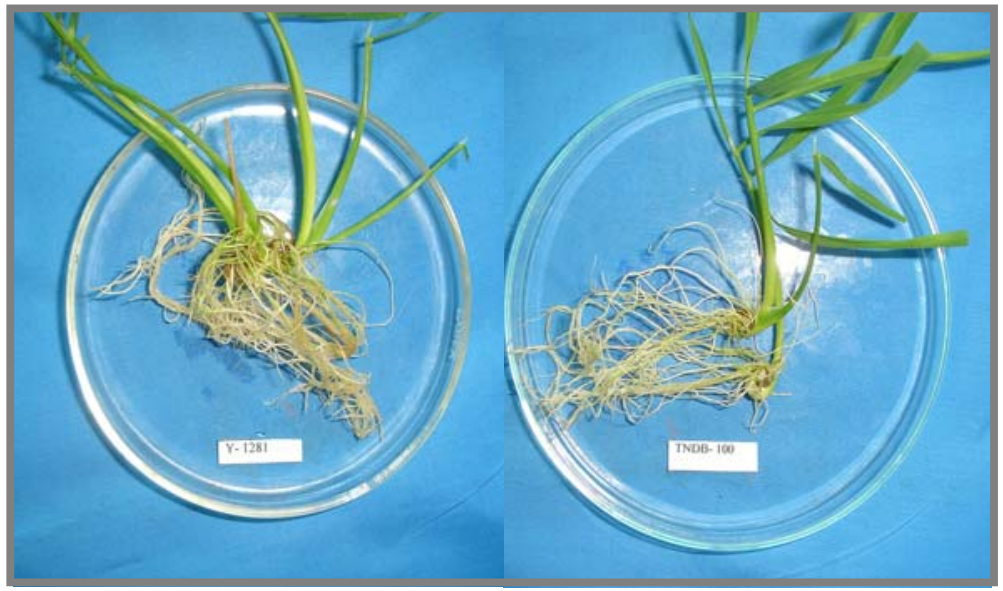

Plate 3. Root induction from shoots of Y-1281 (highest) and TNDB-100 (lowest) on medium containing $2.5 \mathrm{mgl}^{-1} \mathrm{MET}$ (DAl: 30) 


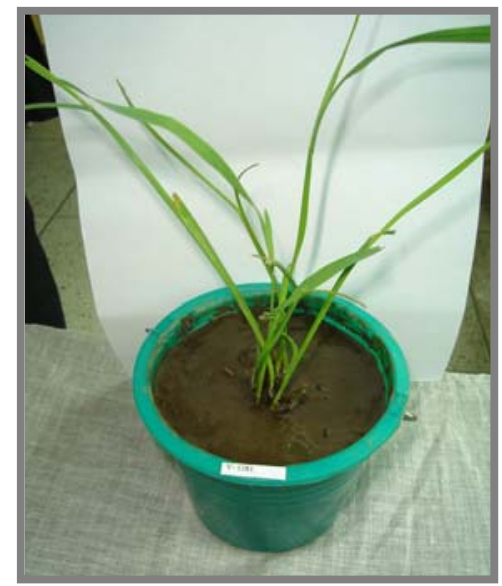

Plate 4. Established plants of $\mathrm{Y}-1281$ in plastic pot showing tillers

\section{References}

Ahmed, M. 2004. Plant regeneration from embryo derived callus of aromatic rice. M.S. Thesis. Dept. Biotech., Bangladesh Agricultural University, Mymensingh.

Bajaj, Y.P.S. 1991. Biotechnology in Agriculture and Forestry 15. Medicinal and Aromatic Plants 111. Springer-verlag, Berlin.

Conway, G. and Toenniessen, G. 1999. Feeding the world in the twenty-first century. Nature (Suppl), 402: 55-58.

Deng, X.M. and Yang, Z.P. 1998. Establishment of an efficient embryogenic transformation system in rice and regeneration of herbicide resistant transgenic rice plants. Acta Agriculturae Shanghai., 14(2): 29-34.

Elhag, H.M., El-Dominaty, M.M., El-Feraly, F.S., Mossa, J.S. and El-Olemy, M.M. 1992. Selection and micropropagation of high artemisinin producing clones of Artemisia amma L-Phytotherapy Res., 6: 20-24.

Khan, Z.I. Hussain, A. and Sadiq, M. 2000. Role of Plant Growth Regulators (Auxin and Cytokinin) in Callus Induction in Rice (Oryza sativa L.) C.V. DM-25. Pakistan J. Biol. Sci., 3 (1): 157-159.

Khush, G.S. 1984. In: JP Gustafsom (ed). Gene manipulation in plant improvement, plenum,. N.Y., pp. 61-94.

Kyozuka, J., Hayashi, Y. and Shimmaoto, K. 1987. High frequency plant regeneration from rice protoplast by novel nurse culture methods. Mol. Gen. Genet., 201: 408-413.

Liu, C.Z., Moon, K.H., Honda, H. and Kobayashi, T. 2001. Enhanced regeneration of rice (Oryza sativa L.) from embryogenic callus by light irradiation in growth phase. J. Bioscience and Bioengineering. 91(3): 319-321.

Luo, T.K., Zhang, X.L., Zhang, X.Y. Liu, Q., Zhu, X.F. and Lin, G.S. 2004. Effects of the proportion of $\mathrm{NH}_{4}^{+}$and $\mathrm{NO}_{3}^{-}$on callus formation and plant regeneration of embryo of indica rice (Variety zhenshan 97). J. Yunnan Agril. Unive. 19(2): 131134.

Lutts, S., Kinet, J.M. and Bouharmont, J. 2001. Somaclonal variation in rice after two successive cycles of mature embryo derived callus culture in the presence of $\mathrm{NaCl}$. Biologia-Plantarum. 44: 4.

Murashige, T. and Skoog, F. 1962. A revised medium for rapid growth and bioassy with tobacco tissue cultures. Physiol. Plant. 15: 473-497.

Russel, D.F. 1986. MSTAT-C. Crop and Soil Sci. Dept., Mitchgan State Univ., USA.

Toenniessen, G.H. 1990. In: Higo, K. (ed). $2^{\text {nd }}$ International workshop on molecular biology of rice, Kawaski Medical School, Okayama, p. 39.

Zhang, L., Xie, C.H. and Li, W.F. 2002. Studies on tissue of mature embryo in rice. Hybrid-Rice. 17(2): 46. 